\title{
HUBUNGAN ANTARA KETERAMPILAN MEMBACA DENGAN SELF ESTEEM MAHASISWA
}

\author{
Elly Syahadati ${ }^{1}$, Desi Sri Astuti², Hamid Asman ${ }^{3}$ \\ Pendidikan Bahasa Inggris, Fakultas Bahasa dan Seni IKIP PGRI Pontianak \\ syahadati1979@gmail.com
}

\begin{abstract}
Abstrak
Penelitian studi kasus ini dimaksudkan untuk mecari tahu apakah ada hubungan antara keterampilan membaca dengan self-esteem mahasiswa semestrer dua Program Studi Bahasa Inggris IKIP PGRI Pontianak tahun akademik 2016/2017. Adapun kelas yang menjadi sampel adalah kelas A sore yang berjumlah 34 orang. Penelitian ini menggunakan metode analisis korelasi, yakni studi yang membahas tentang derajat hubungan antara variabel-variabel. Pengumpulan data dalam penelitian ini menggunakan dua metode yaitu soal tertulis dan kuesioner. Dari data yang diperoleh dapat disimpulkan bahwa harga diri/self esteem memainkan peran penting dalam keterampilan membaca. Mahasiswa dengan harga diri yang tinggi cenderung tidak merasa malu atau takut ketika mereka membaca teks. Sementara mahasiswa dengan harga diri yang rendah cenderung takut melakukannya.
\end{abstract}

Kata kunci: mahasiswa, keterampilan membaca, teks bacaan, self esteem

\begin{abstract}
This case study was intended to know the correlation between reading skill and self esteem for the second semester students of English Education Program of IKIP PGRI Pontianak in the academic year of 2016/2017, there were 34 participants from class A Afternoon. This study used the coreelation analysis method. For the data collecting, the researcher used written and questionaire tests. From the data analysis, it could conclude that self esteem was very important in reading skill. Student who has the higher self esteem would be more appreciate in reading the texts, and student who has the lower self esteem would not be appreciate in reading.
\end{abstract}

Keywords: students, reading skill, reading texts, self esteem.

\section{PENDAHULUAN}

Membaca adalah salah satu cara berkomunikasi dalam bentuk tertulis, dengan membaca kita akan mendapatkan informasi. Dengan kata lain, seseorang harus memahami atau mengerti ide-ide dari bacaan tersebut. Membaca 
memungkinkan orang untuk mengetahui informasi dari berbagai teks, ditulis atau dicetak, informasi dari surat kabar, majalah, iklan, brosur, dan sebagainya.

Menurut Aebersold dan Field (1997: 15), membaca adalah apa yang terjadi ketika orang melihat teks dan menetapkan makna simbol-simbol yang ditulis dalam teks itu. Selain itu, William (1984: 12) mendefinisikan membaca sebagai proses dimana seseorang melihat dan memahami apa yang telah ditulis. Dari kedua definisi tersebut dapat disimpulkan bahwa membaca adalah proses menempatkan makna untuk mendapatkan informasi dengan memahami teks tertulis.

Mahasiswa harus memiliki kemampuan untuk memahami teks dalam keterampilan membaca. Pemahaman teks bervariasi sesuai dengan pengetahuan baik seseorang dari kata dan tujuan seseorang dalam membaca. Hal ini diperlukan untuk memiliki pemahaman yang memadai sesuai tujuan karena merupakan pusat membaca. Mahasiswa perlu memahami bagaimana teks bekerja dan apa yang di lakukan ketika membaca, dan harus mampu memantau pemahaman sendiri (Grabe dan Stoller, 2002: 9-10).

Kesulitan dalam keterampilan membaca yang biasanya dihadapi mahasiswa adalah memahami teks, mengetahui kata-kata dalam teks dan pemahaman yang kurang mengenai pesan dari teks. Mahasiswa tahu kata-kata tetapi tidak tahu arti dari teks. Beberapa mahasiswa mengetahui arti dari kata-kata atau kosakata dari teks tetapi tidak bisa mendapatkan pesan teks. Dan ada beberapa mahasiswa yang tidak tahu makna teks sama sekali. Di sisi lain, pembaca mengalami kesulitan untuk memahami ide umum, untuk mengidentifikasi gagasan utama, informasi eksplisit dan implisit serta referensi kata tertentu.

Kesulitan-kesulitan yang dihadapi mahasiswa biasanya dipengaruhi oleh self-esteem (harga diri). Harga diri adalah evaluasi individu yang lazim dalam mempertahankan diri yang berkaitan dengan dirinya sendiri, mengungkapkan sikap persetujuan atau ketidaksetujuan, dan menunjukkan sejauh mana seorang individu percaya bahwa dirinya mampu, signifikan, sukses, dan layak (Coopersmith dalam Brown, 2000: 103). Evaluasi tersebut terbentuk melalui pengalaman yang berulangulang mengenai keberhasilan dan kegagalan, pengalaman orang lain, dan penilaian diri dalam kaitannya dengan diri yang ideal. 
Watts (2004: 8) menyatakan bahwa harga diri adalah bagaimana berpikir dan merasa tentang diri sendiri. Hal ini mengacu pada bagaimana kita berpikir tentang cara melihat, kemampuan, hubungan dengan orang lain, dan harapan untuk masa depan. Harga diri adalah keyakinan pada diri kita sendiri, harga diri yang tinggi pada anak-anak akan membawa mereka melalui saat mereka tumbuh dewasa. Harga diri dianggap sebagai salah satu faktor efektif penting karena keberhasilan atau kegagalan seseorang sebagian besar tergantung pada derajat atau harga diri seseorang. Harga diri memainkan peran penting dalam keterampilan membaca. Mahasiswa dengan harga diri yang tinggi cenderung kurang merasa malu atau takut ketika mereka membaca teks. Sementara mahasiswa dengan harga diri yang rendah cenderung takut melakukannya.

Berdasakan pada uraian yang di jelaskan dapat disimpulkan bahwa keterampilan membaca dapat dikuasai dengan baik apabila mahasiswa yang memiliki self-esteem tinggi lebih baik dan cepat memahami isi bacaan dari sebuah teks. Secara empiris (lapangan) belum teruji kebenarannya, hal inilah yang mendorong peneliti untuk mecari tahu apakah ada hubungan antara keterampilan membaca dengan self-esteem.

\section{METODE}

Berpijak pada masalah dan tujuan yang telah dirumuskan, maka dalam penelitian ini digunakan metode analisis korelasi. Analisis korelasi yakni studi yang membahas tentang derajat hubungan antara variabel-variabel. Metode penelitian dipilih karena untuk mempelajari hubungan dua variabel atau lebih, yakni hubungan dalam satu variabel dengan variasi dalam variabel lain (Arifin, 2011:48). Dalam hal ini dapat melihat hubungan keterampilan membaca dengan self-esteem. Hal ini juga didukung oleh pernyataan Sukardi (2011:166) "penelitian korelasi adalah suatu penelitian yang melibatkan tindakan pengumpulan data guna menentukan, apakah ada hubungan antara dua variabel atau lebih”.

Penelitian ini dilakukan di IKIP PGRI Pontianak dengan populasi seluruh mahasiswa semester II Bahasa Inggris IKIP PGRI Pontianak tahun akademik 2016/2017 yang terdiri dari A, B pagi dan A, B sore. 
Tabel 1.

Daftar Kelas Semester II Prodi Pendidikan Bahasa Inggris

\begin{tabular}{cc} 
KELAS & JUMLAH \\
\hline A Pagi & 34 \\
\hline B pagi & 34 \\
\hline A sore & 34 \\
\hline B sore & 34 \\
\hline JUMLAH & 170
\end{tabular}

Adapun kelas yang terpilih menjadi sampel adalah kelas A sore semester II Bahasa Inggris IKIP PGRI Pontianak tahun akademik 2016/2017 yang berjumlah 34 orang. Pengumpulan data dalam penelitian ini menggunakan dua metode yaitu metode soal dan kuesioner.

\section{Instrumen Penelitian}

a) Tes Keterampilan Membaca

Tes keterampilan membaca digunakan untuk mengumpulkan data tentang keterampilan membaca mahasiswa. Soal yang digunakan adalah objektif tes dalam bentuk pilihan ganda.

b) Kuesioner Self-esteem

Kuesioner digunakan untuk mendapatkan data mahasiswa tentang Selfesteem. Christensen $(2008,127)$ menyatakan bahwa kuesioner adalah laporan instrumen pengumpulan data yang masing-masing peserta penelitian mengisi sebagai bagian dari studi penelitian.

Jenis pertanyaan kuesioner dapat dibagi menjadi dua: pertanyaan terbuka dan tertutup. Pertanyaan terbuka memungkinkan responden untuk memberikan jawaban mereka sendiri, sementara pertanyaan tertutup membutuhkan responden untuk memilih dari sejumlah tanggapan yang telah ditentukan atau untuk memilih salah satu alternatif jawaban yang diberikan (Johnson \& Christensen, 2008: 56). Peneliti menggunakan pertanyaan tertutup. Bentuk item adalah objektif. Hal ini digunakan untuk membuat mahasiswa lebih mudah untuk menjawab. Kuesioner digunakan untuk mengklasifikasikan mahasiswa menjadi dua kelompok: 
mahasiswa yang memiliki Self-esteem yang tinggi dan yang memiliki harga diri yang rendah.

\section{Teknik Analis Data}

Setelah peneliti melakukan penelitian di lapangan dan mengumpulkan datadata, maka selanjutnya yang dilakukan adalah mengalisi data.

\section{a) Analisis Korelasi}

Uji korelasi dimaksudkan untuk melihat hubungan antara dari dua hasil pengukuran atau dua variabel yang diteliti, untuk mengetahui derajat hubungan antara variabel X (keterampilan membaca) dengan variabel Y (Self-esteem). Pada penelitian ini peneliti menggunakan teknik person product moment correlation, dimana dalam perhitungannya peneliti menggunakan perhitungan SPSS.

Untuk mengidentifikasi tinggi rendahnya koefisien korelasi atau memberikan interpretasi koefisien korelasi digunakan tabel kriteria pedoman untuk koefisien korelasi sebagai berikut:

Tabel 2.

Pedoman Untuk Interpretasi Koefisien Korelasi

\begin{tabular}{cl}
\hline Interval Koefisian & \multicolumn{1}{c}{ Tingkat Hubungan } \\
\hline $0,800-1,00$ & Sangat Tinggi \\
$0,600-0,799$ & Tinggi \\
$0,400-0,599$ & Cukup \\
$0,200-0,399$ & Rendah \\
$0,000-0,199$ & Sangat rendah (tak berkorelasi)
\end{tabular}

(Sugiyono, 2010:184) 
b) Analisis Regresi

Analasis regresi digunakan untuk menelaah hubungan antara dua variabel atau lebih, terutama untuk menelurusi pola hubungan yang modelnya belum diketuhui dengan sempurna, atau untuk mengetehui bagaimana variasi dari beberapa variabel independen mempengaruhi variabel dependen dalam satu fenomena yang kompleks. Dalam penelitian ini, peneliti menghitung dengan SPSS.

\section{HASIL DAN PEMBAHASAN}

Berdasarkan penelitian yang telah dilakukan, maka dapat ditarik kesimpulan bahwa adanya hubungan yang positif dan signifikan antara self-esteem dengan keterampilan membaca. Berdasarkan tabel koefisien korelasi, diperoleh nilai Sig variabel kreativitas 0.000 , hal itu dapat dinyatakan bahwa variabel bebas memiliki korelasi terhadap keterampilan membaca, karena nilai Sig $\leq 0.005$, dan model korelasi dapat digunakan untuk mengetahui besarnya keterampilan membaca. Hal ini menunjukkan bahwa adanya hubungan antara self- esteem dengan ketrampilan membaca.

Mahasiswa yang memiliki self-esteem atau harga diri tinggi memiliki tanggung jawab sendiri, bisa menghormati orang lain.. Mahasiswa dengan selfesteem tinggi ditantang untuk menjadi yang terbaik sebagaimana mestinya. Para mahasiswa yang memiliki tingkat self-esteem tinggi berharap dapat melakukannya dengan baik dalam pencapaian mereka dan mencoba untuk menjadi sukses (Guindon, 2010: 155). Mereka diundang untuk mengaitkan kesuksesan mereka dengan kemampuan mereka, dan membuat penyisihan untuk keadaan dalam menafsirkan kegagalan mereka. self-esteem yang lebih besar mengarah pada usaha dan ketekunan yang lebih besar dalam menghadapi kemunduran, bahkan jika seseorang terganggu dalam pembacaannya, kemungkinan besar akan kembali ke tugas awalnya (Woolfolk, 2007: 333).

Sementara itu, para mahasiswa yang memiliki self-esteem rendah memiliki karakteristik yang berlawanan. Mereka cenderung mengharapkan yang terburuk, lebih sedikit usaha untuk mengerjakan tugas mereka, terutama tantangan dan 
tantangan, dan kurang berhasil (Dolan, 2007: 155). Bahkan, ketika mahasiswa yang memiliki self-esteem rendah meraih kesuksesan, mereka kurang cenderung mengaitkan kesuksesan mereka dengan kemampuan mereka untuk menikmatinya. Dengan kata lain, mahasiswa dengan self-esteem tinggi terus maju secara akademis sementara mereka yang memiliki self-esteem rendah tertinggal.

\section{DAFTAR PUSTAKA}

Aebersold, J. A. and M. L. Field. (1997). From Reading to Reading Teacher: Issues and Strategies for Second. Language Classrooms. Cambridge: Cambridge

Arifin, Z. ( 2011). Penelitian Pendidikan: Metode Paradigma Baru. Bandung: Remaja Rosdakarya.

Brown, H.Douglas. 2000. Principles of Language Learning and Teaching fourth edition. San Fransisco State University: Long March.

Dolan, Simon L. 2007. Stress Self-Esteem Health and Work. New York : Palgrave Macmillan.

Grabe, William \& Stollen. 2002. Reading in Second Language. Cambridge : Cambridge University Press.

Guindon, Mary H. 2010. Self-Esteem : Across The Lifespan. New York : Taylor and Francis Group, LLC.

Johnson, R.B. \& Christensen, L. B. (2008). Educational Research: Quantitative, Qualitative, and Mixed Approaches (3rd ed.). Thousand Oaks, CA : Sage.

Sukardi. (2011). Metodologi Penelitian Pendidikan. Jakarta: Bumi Aksara.

Watts, Franklin. 2004. Self-Esteem. Minnesota : Smart Apple Media.

William, Eddie. 1984. Reading in the Language Classroom. London: Modern English Publication. 
Jurnal Pendidikan Bahasa, Vol. 7, No. 2, Desember 2018

Woolfolk Hoy, A. (2004). Educational Psychology 9th Edition. USA : Pearson 